\title{
Досвід проведення високодозової хіміотерапії з аутологічною трансплантацією гемопоетичних стовбурових клітин дорослим пацієнтам у Національному інституті раку
}

\author{
Національний інститут раку, Київ \\ Одержано: 25.07.2020 \\ Прийняо до друку: 03.08.2020 \\ DOI: $10.32471 /$ clinicaloncology.2663-466X.37-1.27084
}

\begin{abstract}
У статті наведено короткий історичний огляд використання високодозової хіміотерапії (ВдХТ) при лікуванні множинної мієломи та лімфом. Стаття містить результати основних досліджень щодо ефективності даного методу при різних лімфопроліферативних захворюваннях, які дозволяють розглядати його як золотий стандарт терапії I лінії множинної мієломи та як найбільш ефективну терапію у пацієнтів з рефрактерними чи рецидивними формами лімфом, зокрема лімфоми Ходжкіна та дифузної В-великоклітинної лімфоми. Наведено дані щодо використання ВдХТ при несприятливому перебігу Саркоми Юїнга. На підставі рекомендацій Європейської асоціації трансплантації кісткового мозку (European Society for Blood and Marrow Transplantation - EBMT) наведено орієнтовні потреби в даному методі в Україні. Представлено власні результати дослідження ефективності та ускладнень терапії 36 пацієнтів з рецидивом та рефрактерною формою лімфоми Ходжкіна та неходжкінських лімфом, первинною множинною мієломою та саркомою Юїнга високого ризику, що отримали ВДХТ з аутотрансплантацією гемопоетичних стовбурових клітин у відділенні онкогематології Національного інституту раку та у яких період спостереження становить понад 100 днів.
\end{abstract}

Ключові слова: високодозова хіміотерапія; множинна мієлома; рефрактерна лімфома; рецидив лімфоми, лімфома Ходжкіна; дифузна В-великоклітинна лімфома; Саркома Юїнга; Національний інститут раку.

\section{ВстУП}

Ефект високодозової хіміотерапії (ВДХТ) полягає в терапії високими дозами хіміопрепаратів, що дозволяє подолати хіміорезистентність пухлинних клонів, які залишилися нечутливими до хіміотерапії і стандартних доз. При цьому мієлотоксичну дію високих доз хіміотерапії не враховують, а відновлення кровотворення після аплазії кісткового мозку відбувається за рахунок гемопоетичних стовбурових клітин (ГСК), що вводяться пацієнтові після ВДХТ. У разі проведення аутологічної трансплантації гемопоетичних стовбурових клітин (аутоТГСК) джерелом їх є сам пацієнт, заготівля ГСК проводиться до початку ВДХТ.

Множинна мієлома (ММ). На даний час при ММ ВДХТ $€$ стандартом і проводиться в I лінії терапії для консолідації отриманої відповіді всім пацієнтам віком до 70 років, у яких немає протипоказань.

Уперше про проведення ВДХТ з подальшою аутоТГСК при ММ було повідомлено в 1983 p. McElwain and Powles [1]. 3 того часу ВДХТ є стандартним терапевтичним підходом у терапії I лінії ММ, тому що істотно покращує показники безподійної виживаності (БПВ) і якості життя при низькому рівні смертності, пов'язаної з трансплантацією. У якості кондиціонування (високодозової хіміотерапії при проведенні аутоТГСК) при ММ більшістю центрів використовується введення мелфалану в дозі 200 мг/м. кв. Такий режим на даний час є золотим стандартом для переважної більшості пацієнтів (доза може бути знижена до 140 мг/м. кв у пацієнтів похилого віку, при нирковій недостатності).

На сьогодні опубліковані результати досліджень, у яких показані переваги даного методу терапії для пацієнтів з ММ порівняно з хіміотерапією в стандартних дозах. Наприклад, в дослідженні «IFM90» загальна виживаність (3В) становила 43\% порівняно з 25\% у пацієнтів, які отримали ВДХТ з ТГСК порівняно з пацієнтами, які отримали хіміотерапію в стандартних дозах, виживаність без прогресування становила $16 \%$ порівняно з 8\% відповідно при медіані спостереження 7 років [2.
У дослідженні «MRC Myeloma VII» медіана 3В становила, 42 проти 20 міс відповідно, БПВ - 54 проти 32 міс [3].

За даними останнього статистичного огляду Європейської асоціації трансплантації кісткового мозку (European Bone Marrow Transplantation - EВMT), у 2017 році в Свропі з приводу ММ була виконана 21357 аутологічних ТГСК, що становило 53\% від загальної кількості всіх аутологічних трансплантацій за рік. ММ є найчастішим показанням для проведення аутологічних трансплантацій [4].

Лімфоми. Проведення ВДХТ в програмі терапії рецидиву й рефрактерних форм лімфоми Ходжкіна і дифузної В-великоклітинної лімфоми (найпоширенішої неходжкінської лімфоми) на сьогодні $є$ світовим стандартом як метод, що має найбільш високий терапевтичний потенціал.

Лімфома Ходжкіна (ЛХ). Перше рандомізоване дослідження з вивчення ролі ВДХТ в лікуванні рецидивів ЛХ було проведено у Великобританії групою British National Lymphoma Investigation (BNLI). Порівнювалася ефективність ВДХТ за схемою ВЕАМ (кармустин/етопозид/цитарабін/мелфалан) з подальшою аутоТГСК і поліхіміотерапія аналогічними препаратами в немієлоаблативних дозах (схема mini-BEAM). 20 пацієнтів отримали курс ВДХТ за схемою ВЕАМ + аутоТГСК, 20 інших терапію за схемою тіпі-ВЕАМ. У групі ВЕАМ померли 5 хворих (2 - $з$ причин, пов'язаних з терапією, 3 - через прогресію захворювання). У групі mini-BЕАМ померли 9 хворих (усі від прогресування захворювання). Відмінності в безпосередній ефективності терапії були статистично незначущими $(\mathrm{p}=0.318)$, однак 3-річна БПВ і виживаність без прогресії були значно вищими в групі ВЕАМ + аутоТГСК ( $\mathrm{p}=0,025$ i p=0,005 відповідно). Набір пацієнтів у дослідження було припинено раніше запланованого через суттєву перевагу результатів терапії, які відмічали в групі пацієнтів, які отримували ВДХТ [5].

Роль ВДХТ при первинно-рефрактерному перебігу ЛХ довгий час залишалася дискутабельною, хоча в ряді досліджень була показана iї висока ефективність в лікуванні цієї групи пацієнтів з вкрай несприятливим прогнозом. 
ЕВМТ було ініційовано ретроспективне мультицентрове дослідження з вивчення ефективності ВДХТ в лікуванні пацієнтів з первинно-рефрактерним перебігом ЛХ після хіміотерапії І лінії. Зі 175 пацієнтів 75 отримали ВДХТ відразу після відсутності ефекту від застосування індукційних режимів, інші 100 хворих попередньо отримали індукційну терапію II лінії в звичайних дозах за різними схемами поліхіміотерапії. Після проведення ВДХТ повну відповідь (ПВ) на лікування було досягнуто у $30 \%$ пацієнтів, часткову відповідь (ЧВ) - у 28\%. Медіана спостереження становила 73 міс, 5-річна ЗВ і БПВ, становили, відповідно, 36 і 32\% [6].

Провівши аналіз публікацій результатів проведених досліджень, у Центрі раку Sloan Kettering (Memorial Sloan Kettering Cancer Center - MSKCC) ініціювали терапевтичний протокол для оцінки довгострокових результатів ВДХТ у пацієнтів з первиннорефрактерним перебігом ЛХ.

391 пацієнта досліджуваної групи 16 згодом були виключені 3 нього. При медіані спостереження 10 років БПВ, безрецидивна виживаність (БРВ) і ЗВ становили, відповідно 45, 49 і $48 \%$. На показник БРВ впливала хіміочутливість до сальвадж-терапії ( $\mathrm{p}=0,001) .10$-річна БРВ, БПВ і ЗВ у пацієнтів з хіміочутливістю становили відповідно 60, 62 і 66\% проти 19, 23 і 17\% в групі незадовільної відповіді на хіміотерапію в стандартних дозах $(\mathrm{p}<0,001)$. Результати цього дослідження дозволили стверджувати, що для пацієнтів з первинно-рефрактерним перебігом ЛХ, чутливої до хіміотерапії ІІ лінії, подальша ВДХТ з аутоТГСК $€$ найкращою терапевтичною опцією [7]. В останньому опублікованому річному звіті ЕВМТ (2017) повідомлено про проведення в Європі 2152 вДХТ при ЛХ.

Дифузна В-великоклітинна лімфома. У лікуванні хіміочутливого рецидиву дифузної В-великоклітинної лімфоми проведення ВДХТ після індукції ремісії за схемами DHAP чи ICE є стандартним терапевтичним підходом. Так, у дослідженні PARMA пацієнти, які відповіли на терапію за схемою DHAP, були рандомізовані у дві гілки: продовження поліхіміотерапії за схемою DHAP і проведення променевої терапії або ВДХТ за схемою ВЕАС (кармустин, етопозид, цитарабін, циклофосфамід) з аутоТГСК. ЗВ на стандартнодозову хіміотерапію становила 5\%; серед пацієнтів з рецидивами після хіміотерапії показник 3В становив 64\%, а серед рецидивів під час хіміотерапії 3В становила $21 \%$. У пацієнтів групи трансплантації було зафіксовано 3 випадки смерті від ускладнень трансплантації і жоден - у групі без трансплантації. Медіана спостереження становила 63 міс. Частота відповіді становила 84 \% після ВДХТ та 44\% - після хіміотерапії без ВДХТ. 5-річна БПВ і ЗВ в 2 групах становили відповідно 46 і 12\% (p=0,0001) та 53 і 32\% (p=0,038) у пацієнтів в групі ВДХТ і в групі терапії зі стандартними дозами [8].

На сьогодні процедура ВДХТ з аутоТГСК доступна для пацієнтів в Україні.

Відповідно до рекомендацій ЕВМТ, кількість центрів проведення трансплантації кісткового мозку має становити 1 на 1 млн населення [9]. Тобто лише у м. Київ має працювати 4-5 центрів трансплантації. Усього в Україні орієнтовна кількість центрів трансплантації повинна становити близько 40. Кожен з таких центрів щорічно має проводити не менше 25-30 процедур ВДХТ + аутоТГСК. Щорічна потреба у проведенні ВДХТ + аутоТГСК дорослим пацієнтам в Україні становить більш ніж 2000 процедур.

До 2016 р. в Україні працювало 3 центри трансплантації гемопоетичних стовбурових клітин: Київський центр трансплантації кісткового мозку (проведення аутологічних ТГСК дорослим пацієнтам), Гематологічний центр Національної дитячої спеціалізованої лікарні «ОХМАТДИТ» (проведення аутологічних та алогенних ТГСК дітям) та Відділення дитячої онкології Національного інституту раку (НІР), яке використовує метод ВДХТ + аутоТГСК при лікуванні солідних пухлин у дітей. Таким чином, в Україні існує значний дефіцит центрів, у яких доступне застосування ВДХТ + аутоТГСК.

У відділенні онкогематології НІР наприкінці 2016 р. було розпочато проведення даного терапевтичного методу, виходячи з внутрішніх ресурсів відділення онкогематології та НІР.
Наданий час у НІР успішно виконано 60 процедур ВДХТ + аутоТГСК у дорослих пацієнтів з гемобластозами та солідними пухлинами. Так, виконано 22 трансплантації у хворих з рецидивними та рефрактерними формами ЛХ, $23-$ у хворих з ММ, 2 - саркомою Юїнга, 3 - рецидивом неходжкінської лімфоми.

\section{МАТЕРІАЛИ І МЕТОДИ}

У даній роботі представлено результати аналізу передтрансплантаційного статусу, характеристики трансплантата, токсичності терапії та іiї ефективності у 36 пацієнтів з рецидивом та рефрактерною формою ЛХ та неходжкінських лімфом, первинною множинною мієломою та саркомою Юїнга високого ризику, що отримали ВДХТ з аутоТГСК у відділенні онкогематології НІР та у яких наявний період спостереження становить понад 100 днів (табл. 1).

Діагноз рецидиву або рефрактерної лімфоми був верифікований шляхом проведення повторної біопсії зі здійсненням гістологічного та імуногістохімічного дослідження.

Статус перед ВДХТ та на день +100 після ВДХТ оцінювали у пацієнтів з лімфомами за критеріями B.D. Chesson та співавторів $[10,11]$, у пацієнтів з множинною мієломою - за критеріями IMWG [12].

Серед досліджуваної групи пацієнтів було 16 чоловіків та 20 жінок, середній вік становив $35,8 \pm 9,9$ року (21-60 років).

3 метою мобілізації стовбурових клітин периферичної крові було використано наступні режими: DHAP, IGEV, GVD, Cy + G-CSF, G-CSF ( \pm плериксафор), етопозид в високих дозах. Кількість процедур аферезу під час одного мобілізаційного циклу становила від 1 до 2 , у середньому $-1,3 \pm 0,5$ процедури на 1 пацієнта. Дев'ять пацієнтів належали до групи високого ризику невдалої колекції, 4 з них не вдалося зібрати достатню для проведення ВДХТ кількість стовбурових клітин (більше 2 млн на 1 кг маси тіла хворого). Кількість стовбурових клітин периферичної крові розраховувалася за кількістю клітин CD34+ у продукті аферезу. Процедури аферезу проводилися на клітинних сепараторах COM.TEC та AMICUS фірми Fresenius Kabi.

Кількість клітин CD34+ в трансплантаті становила 3,3-21,0 млн/кг маси тіла пацієнта, у середньому 7,1 3,96 млн/кг маси тіла пацієнта.

У пацієнтів з лімфомами в якості режиму кондиціонування використовували режим LEAM, аналогічний найпоширенішому блоку ВЕАМ із заміною кармустину ломустином через відсутність кармустину в Україні: ломустин, етопозид, цитарабін, мелфалан. У пацієнтів з ММ використовувався режим Mel 200 мг/м. кв. При саркомі Юїнга кондиціонування проводилося за схемами «HD Melph-Etop» (мелфалан та етопозид) та «BU-MEL» (бусульфан та мелфалан).

Серед 20 пацієнтів з лімфомами (18 з ЛХ, 2 з неходжкінською лімфомою) більшість мала вкрай несприятливий прогноз перебігу захворювання: у 12 пацієнтів відмічали рефрактерну форму, 5 із 8 пацієнтів з рецидивом лімфоми не відповіли на I лінію протирецидивної хіміотерапії (рефрактерний рецидив). Статус захворювання у пацієнтів злімфомами перед проведенням ВДХТ був наступним: ЧВ зареєстровано у 8 пацієнтів, ПВ - у 10.

У пацієнтів з ММ ВДХТ була проведена як етап первинної терапії. ПВ перед проведенням ВДХТ була зареєстрована у 1 пацієнта, дуже добра ЧВ - 7 пацієнтів, часткова відповідь у 4 пацієнтів, мінімальна відповідь - у 2 пацієнтів.

У пацієнтів із саркомою Юїнга ВДХТ була проведена при досягненні ПВ згідно з протоколом «EURO-E.W.I.N.G.99».

\section{РЕЗУЛЬТАТИ}

Відновлення рівня нейтрофілів понад 0,5 Г/л у середньому відбувалося на $11,5 \pm 2,4$ дня (8-20-й день), тромбоцитів

Таблиця 1. Розподіл пацієнтів за нозологіями

\begin{tabular}{|c|c|}
\hline Нозології & Кількість пацієнтів \\
\hline ЛХ & 18 \\
\hline Неходжкінські лімфоми & 2 \\
\hline Множинна мієлома & 14 \\
\hline Саркома Юїнга & 2 \\
\hline
\end{tabular}


до 20 Г/л без потреби у трансфузіях тромбоконцентрату на 16,1 44,2 дня (10-26-й день).

Ефективність терапії. Визначення ефективності терапії проводилося на день $+100 \pm 14$ після ВДХТ за зазначеними вище критеріями. Порівняння статусу хвороби до та після ВДХТ наведено в табл. 2.

Таблиця 2. Статус хвороби у пацієнтів перед та після ВДХТ

\begin{tabular}{lcc}
\hline \multicolumn{3}{c}{ Статус хвороби у пацієнтів, $\mathbf{n}(\%)$} \\
\hline Мо ВДХТ & Після ВДХТ \\
\hline ПВожинна мієлома - 14 пацієнтів & $1(7)$ & $8(58)$ \\
Дуже гарна ЧВ & $7(50 \%(7)$ & $2(14)$ \\
ЧВ & $4(29)$ & $3(21)$ \\
Мінімальна відповідь & $2(14)$ & - \\
Прогресія & - & $1(7)$ \\
ЛХ - 18 пацієнтів & \\
ПВ & & \\
ЧВ & $10(56)$ & $16(89)$ \\
Прогресія & $8(44)$ & $0(0)$ \\
Неходжкінські лімфоми - 2 пацієнти & $0(0)$ & $2(11)$ \\
ПВ & $1(50)$ & \\
ЧВ & $1(50)$ & $0(50)$ \\
Прогресія & $0(0)$ & $1(50)$ \\
Саркома Юїнга - 2 пацієнти & $2(100,0)$ & $2(100,0)$ \\
ПВ &
\end{tabular}

Загалом у досліджуваній групі спостерігалося поглиблення відповіді з часом. При цьому 2-річна БПВ становила 75,9 $\pm 7,5 \%$ в загальній групі, 2-річна БПВ для пацієнтів із Саркомою Юїнга склала $50 \pm 3,5 \%$, пацієнтів з ЛХ $-75,8 \pm 10,7 \%$, для па-

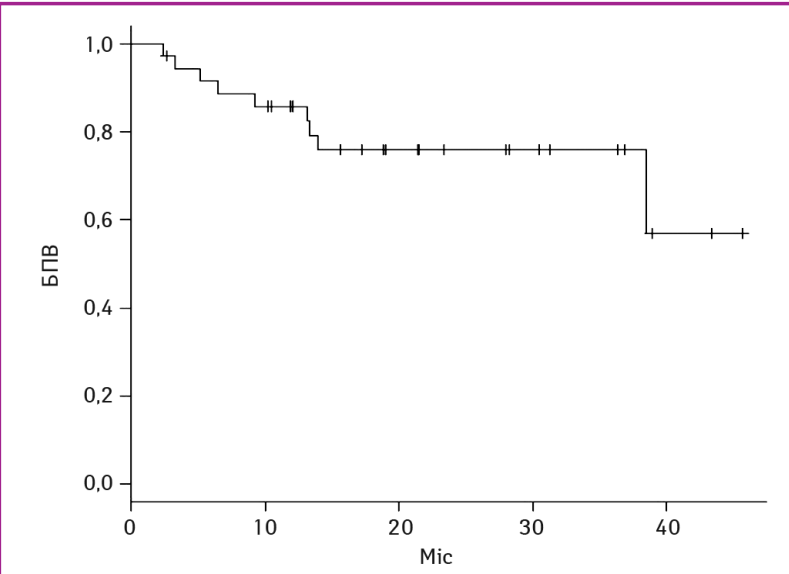

Рис. 1. БПВ в загальній групі

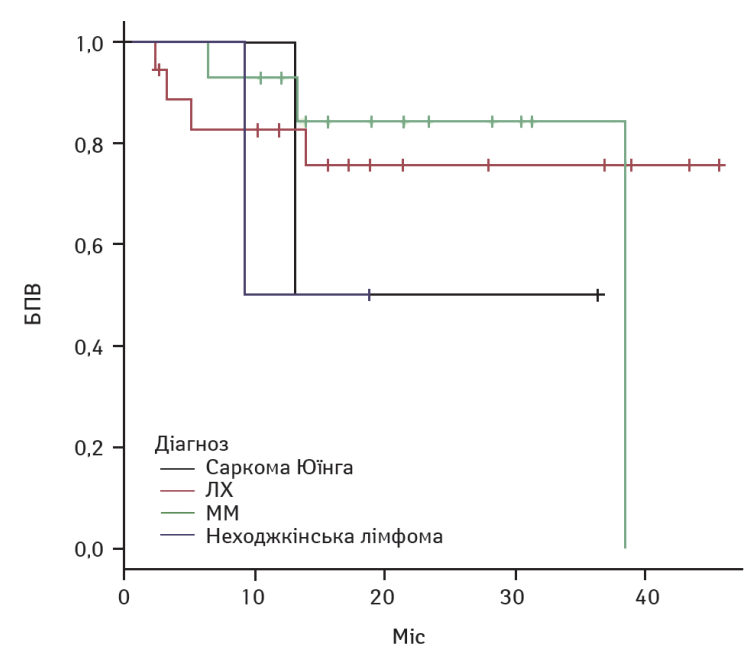

Рис. 2. БПВ залежно від нозології цієнтів з ММ $-84,3 \pm 10,2 \%$, для пацієнтів з неходжкінською лімфомою $-50 \pm 3,5 \%$.

Один пацієнт з лімфомою та один пацієнт з ММ померли від прогресії захворювання на 4-й та 8-й місяці після проведення трансплантації.

Результати БПВ та ЗВ у загальній групі та БПВ та ЗВ залежно від нозології наведено на рис. 1-4.

Токсичність ВДХТ. Серед ускладнень ВДХТ переважала гематологічна токсичність: нейтропенію 3-4 ступеня виявляли у 36 (100\%) пацієнтів, анемію 3-4 ступеня - у 16 хворих $(44,0 \%)$, тромбоцитопенію 3-4 ступеня - у 36 (100\%). Фебрильна нейтропенія розвинулася у $26(72,2 \%)$, інші інфекційні ускладнення були виявлені у 10 хворих $(27,8 \%)$, серед них інфікування зони центрального венозного катетера, сечова інфекція, нейтропенічний ентероколіт, синусит, пневмонія.

Серед інших ускладнень у окремих пацієнтів були виявлені наступні. Гіпоальбумінемію відмічали у 6 хворих $(13,6 \%)$, гіпоглобулінемію - у 5 хворих $(11,4 \%)$, троє хворих $(8,3 \%)$ потребували парентерального харчування, один хворий мав психічні розлади. Прояви кардіотоксичності були виявлені у 3 хворих $(8,3 \%)$, біль - у 6 хворих $(16,7 \%)$. Шкірний висип відмічали у 4 пацієнтів $(11,1 \%)$.

Трансфузії еритроцитів отримали 9 пацієнтів (після кондиціонування з режимом LEAM), у середньому 2,3 1 1,04 трансфузіі. Трансфузію тромбоконцентрату отримували всі пацієнти, у середньому $-2,12 \pm 1,02$ трансфузіі. Не було жодного випадку смерті від ускладнень під час проведення ВДХТ. Усі пацієнти виписані під амбулаторне спостереження з нормальним трьохпаростковим гемопоезом.

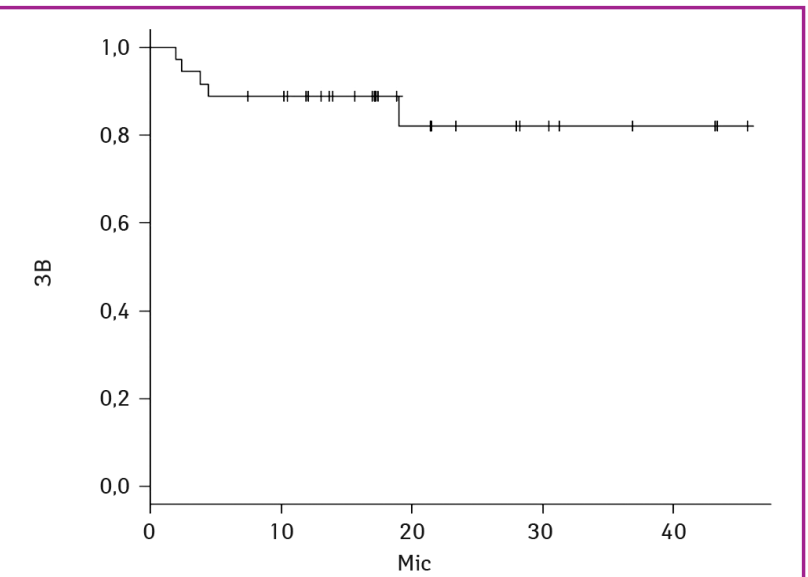

Рис. 3. ЗВ в загальній групі

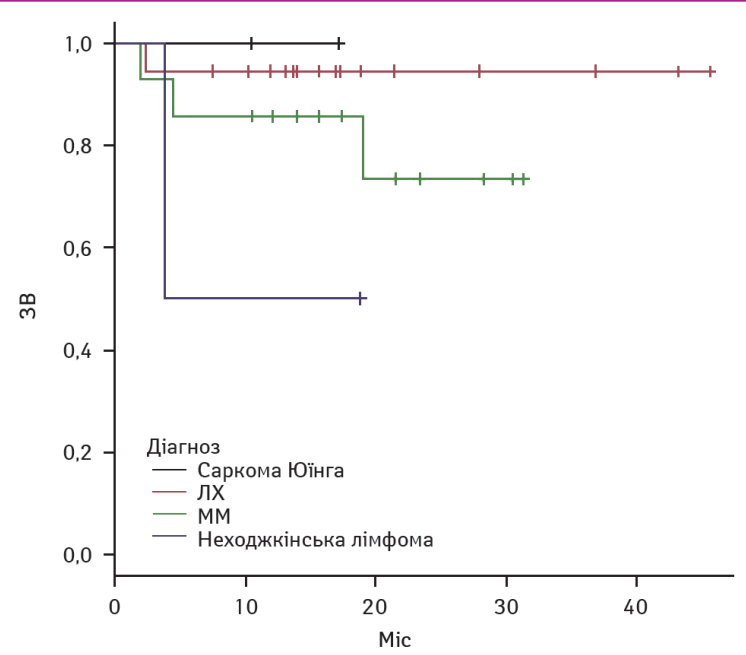

Рис. 4. ЗВ залежно від нозології 
Основні види токсичності за шкалою СТC NCI наведено в табл. 3.

Таблиця 3. Основні види токсичності ВДХТ

\begin{tabular}{lcc}
\hline \multicolumn{1}{c}{ Вид токсичності } & I-II & III-IV \\
\hline Фебрильна нейтропенія & & $26(72,2 \%)$ \\
Нейтропенія & & $36(10 \%)$ \\
Анемія & & $16(44 \%)$ \\
Тромбоцитопенія & & $36(100 \%)$ \\
Кровотеча & $6(13,6 \%)$ & \\
Підвищення рівня трансаміназ & $11(30,5 \%)$ & \\
Мукозит: & & \\
$\quad$ оральний & $27(75 \%)$ & $7(19,4 \%)$ \\
$\quad$ інтестинальний & $7(19,4 \%)$ & $1(2,8 \%)$ \\
Діарея & $17(47,2 \%)$ & $2(5,6 \%)$ \\
Нудота та блювання & $22(61,1 \%)$ & $1(2,8 \%)$ \\
Слабкість & $30(83,3 \%)$ & $2(5,6 \%)$ \\
Набряки & $9(25 \%)$ & \\
\hline
\end{tabular}

Таким чином, починаючи з 2016 р. налагоджено всі етапи проведення ВДХТ + аутоТГСК для дорослих пацієнтів у відділенні онкогематології із сектором ад’ювантних методів лікування НІР. Наш заклад став другим в Україні центром, де проводиться ВДХТ + аутоТГСК для дорослих пацієнтів. На даний час в НІР ця процедура проводиться як для дорослих пацієнтів, так і для дітей. Враховуючи незначну кількість пацієнтів та короткий період спостереження, складно порівнювати результати лікування пацієнтів у нашому відділенні з іншими центрами. За останній рік роботи трансплантаційної команди введено систему контролю якості трансплантату та покращено етапи заготівлі та кріоконсервації стовбурових клітин, проведено навчання медичних сестер щодо роботи центральним венозним доступом, розпочато розробку стандартних операційних процедур у трансплантації. Динаміка збільшення кількості трансплантацій на рік у нашому центрі є наступною (табл. 4):

Таблиця 4. Динаміка збільшення кількості трансплантацій

\begin{tabular}{ccccc}
\hline 2016 р. & 2017 p. & 2018 p. & 2019 p. & Липень 2020 р. \\
\hline 3 & 6 & 10 & 26 & 15 \\
\hline
\end{tabular}

\section{СПИСОК ВИКОРИСТАНОÏ ЛІТЕРАТУРИ}

1. McElwain, T.J., Powles, R.L. (1983). High-dose intravenous melphalan for plasma-cell leukaemia and myeloma. Lancet,2(8354),822-8224. doi: 10.1016/s0140-6736(83)90739-0. 2. Attal, M., Harousseau, J. L., Stoppa, A. M., Sotto, J. J., Fuzibet, J. G., Rossi, J. F., Bataille, R. (1996). A prospective, randomized trial of autologous bone marrow transplantation and chemotherapy in multiple myeloma. The New England Journal of Medicine, 335, 91-97. doi: 10.1056/NEJM199607113350204.

3. Child, J. A., Morgan, G. J., Davies, F. E., Owen, R. G., Bell, S. E., Hawkins, K., ... Selby, P. J. (2003). High-dose chemotherapy with hematopoietic stem-cell rescue for multiple myeloma. The New England Journal of Medicine, 348, 1875-1883. doi: 10.1056/NEJMoa022340.

4. Passweg, J. R., Baldomero, H., Basak, G. W., Chabannon, C., Corbacioglu, S., Duarte, R., ... Kröger, N. (2019) The EBMT activity survey report 2017: a focus on allogeneic HCT for nonmalignant indications and on the use of non-HCT cell therapies. Bone Marrow Transplantation, 54, 1575-1585. doi: 10.1038/s41409-019-0465-9.

5. Linch, D. C., Winfield, D., Goldstone, A. H., Moir, D., Hancock, B., McMillan, A., Hudson, G. V. (1993). Dose intensification with autologus bone-marrow transplantation in relapsed and resistant Hodgkin's disease: Results of a BNLI trial. The Lancet, 341,1051-1054 doi: 10.1016/0140-6736(93)92411-I.

6. Sweetenham, J. W., Carella, A. M., Taghipour, G., Cunningham, D., Marcus, R. Della Volpe, A., ... Goldstone, A. H. (1999). High-dose therapy and autologous stem-cell transplantation for adult patients with Hodgkin's disease who do not enter remission after induction chemotherapy: Results in 175 patients reported to the European Group for Blood and Marrow Transplantation. Journal of Clinical Oncology, 17, 3101-3109. for Blood and Marrow Transplantatio

7. Moskowitz, C. H., Kewalramani, T., Nimer, S. D., Gonzalez, M., Zelenetz, A. D., \& Yahalom, J. (2004). Effectiveness of high dose chemoradiotherapy and autologous stem cel transplantation for patients with biopsy-proven primary refractory Hodgkin's disease. British Journal of Haematology, 124(5), 645-652. doi: 10.1111/j. 1365-2141.2003.04828.x.

8. Philip, T., Guglielmi, C., Hagenbeek, A., Somers, R., Van der Lelie, H., Bron, D., Harousseau, J. L., (1995). Autologous bone marrow transplantation as compared with salvage chemotherapy in relapses of chemotherapy-sensitive non-Hodgkin's lymphoma. The New England Journal of Medicine, 333, 1540-1545. doi: 10.1056/NEJM199512073332305.

9. Passweg, J. R., Baldomero, H., Bregni, M., Cesaro, S., Dreger, P., Duarte, R. F., Madrigal, A. (2013). Hematopoietic SCT in Europe: data and trends in 2011. Bone Marrow Transplantation, 48(9), 1161-1167. doi: 10.1038/bmt.2013.51.

10. Cheson, B. D., Pfistner, B., Juweid, M. E. Gascoyne, R. D, Specht, L, Horning, S.J., ... Diehl, V. (2014). Revised Response Criteria for Malignant Lymphoma. Journal of Clinical Oncology, 25(5), 579-586. doi: 10.1200/JCO.2006.09.2403.

11. Cheson, B. D., Fisher, R. I., Barrington, S. F. Cavalli, F., Schwartz, L. H., Zucca, E., \& Lister, T. A. (2014). Recommendations for Initial Evaluation, Staging, and Response Assessment of Hodgkin and Non-Hodgkin Lymphoma: The Lugano Classification. Journal of Clinical Oncology, 32, 3059-3067. doi: 10.1200/JCO.2013.54.8800.

12. Rajkumar, S. V., Dimopoulos, M. A., Palumbo, A., Blade, J., Merlini, G., Mateos, M. V., ... Miguel, J. F. (2014). International Myeloma Working Group updated criteria for the diagnosis of multiple myeloma. The Lancet Oncology, 15(12), e538-548. doi: $10.1016 / \mathrm{S} 1470-2045(14) 70442-5$.
Опыт проведения высокодовой химиотерапии с аутологической трансплантацией гемопоэтических стволовых клеток взрослым пациентам в Национальном институте рака

Е.В. Кущевой, К.С. Филоненко, А.В. Мартынчик, И.А. Крячок Национальный институт рака, Киев

Резюме. В статье приведен краткий исторический обзор использования высокодозовой химиотерапии (ВДХТ) при лечении множественной миеломы и лимфомы. Статья содержит результаты основных исследований по эффективности данного метода при различных лимфопролиферативных заболеваниях, которые позволяют рассматривать его как золотой стандарт терапии І линии множественной миеломы и как наиболее эффективную терапию у пациентов с рефрактерными или рецидивирующими формами лимфом, в частности лимфомы Ходжкина и диффузной В-крупноклеточной лимфомы. Приведены данные об использовании ВДХТ при неблагоприятном течении Саркомы Юинга. На основании рекомендаций Европейской ассоциации трансплантации костного мозга (European Society for Blood and Marrow Transplantation - EBMT) приведены ориентировочные потребности в данном методе в Украине. Представлены собственные результаты исследования эффективности и осложнений терапии 36 пациентов с рецидивом и рефрактерной формой лимфомы Ходжкина и неходжкинских лимфом, первичной множественной миеломой и саркомой Юинга высокого риска, получивших ВДХТ с аутотрансплантацией гемопоэтических стволовых клеток в отделении онкогематологии Национального института рака и у которых период наблюдения составляет более 100 дней.

Ключевые слова: высокодозовая химиотерапия; множественная миелома; рефрактерная лимфома; рецидив лимфомы, лимфома Ходжкина, дифузная В-крупноклеточная лимфома; саркома Юинга; Национальный институт рака.

\section{Experience of conducting high dose chemotherapy and autologous stem cell transplantation for adult patients at the National Cancer Institute of Ukraine E.V. Kushchevyi, K.S. Filonenko, A.V. Martynchyk, I.A. Kriachok} National Cancer Institute, Kyiv

Summary. The article provides a brief historical overview of the use of high-dose chemotherapy (HDCT) as a part of treatment of multiple myeloma and lymphoma. The article presents the results of the most important clinical trials evaluating the effectiveness of this therapy in various lymphoproliferative diseases, which allow us to consider this method of treatment as the gold standard for the first-line treatment of multiple myeloma and as the most effective therapy in patients with refractory or recurrent forms of lymphoma, including Hodgkin's lymphoma and diffuse large B-cell lymphoma. There are also data regarding the use of HDCT in the unfavorable course of Ewing Sarcoma. Based on the European Bone Marrow Transplant Association recommendations, approximate needs for this method in Ukraine are outlined. The results of treatment efficacy and complications of 36 patients with recurrent and refractory Hodgkin's lymphoma and non-Hodgkin's lymphoma, primary multiple myeloma and high-risk Ewing sarcoma who have received HDCT with autologous stem cell transplantation in the Department of Oncohematology of the National Cancer Institute with follow up period more than 100 days were presented.

Keywords: high-dose chemotherapy; multiple myeloma; refractory lymphoma; recurrent lymphoma; Hodgkin's lymphoma; Diffuse large B-cell lymphoma; Sarcoma Ewing; National Cancer Institute of Ukraine.

Адреса:
Кущевий Євген Вікторович
озо22 Київ, вул. Ломоносова, 33/43
Національний інститут раку
E-mаil: сосовапgо@ukr.net
Correspondence:
Kuschevyy Evgen
$33 / 43$ Lomonosova str., Kyiv 03022
National Cancer Institute
E-mail: cocobango@ukr.net

